\title{
Research.
}

\section{THE EFFECT OF COMPENSATION, DISCIPLINE AND ACHIEVEMENT MOTIVATION ON EMPLOYEE PERFORMANCE}

\author{
Fitri Rezeki ${ }^{1)}$; Rahmat Hidayat ${ }^{2)^{\star}}$ \\ ${ }^{1,2)}$ Department of Management, Universitas Pelita Bangsa, Bekasi, Indonesia \\ 1)fitri rezeki@pelitabangsa.ac.id; ${ }^{2}$ rahmat hidayat@pelitabangsa.ac.id \\ * Corresponding author \\ Received: February 23, 2021; Accepted: May 28, 2021; Published: June 30, 2021 \\ To cite this article: Rezeki, F. \& Hidayat, R. (2021). The effect of compensation, discipline and achievement \\ motivation on employee performance. The Management Journal Of Binaniaga, 6 (1), 13-22. doi: \\ $\underline{10.33062 / \mathrm{mib} . v 6 \mathrm{i} 1.414}$
}

\begin{abstract}
In business matters, it is hoped that, it can create proper employee performance in the context of developing a system that runs in offices. The office must be able to improve and improve the performance in its environment. Some of the most common problems are the Sukamahi Cikarang Pusat Village Office. In terms of service and service to the community and the government related, to reduce morale due to inadequate salaries and benefits, it is a major problem of decreased discipline in work. Researchers who determine the population in this study are employees of the Village Office of the Sukamahi Subdistrict, Cikarang Pusat. After doing the test that partially compensation had no effect on the performance of the employees of the Sukamahi Cikarang Pusat Village Office. This was indicated by the results that work discipline had an effect on the employee performance of the Sukamahi Cikarang Pusat village office as indicated by the research results. . Achievement also has a positive effect on employee performance and this can be seen from the results obtained. From the above statement, it can be ignored that partially Work Discipline and Achievement Motivation on Employee Performance, while Compensation has no effect on Employee Performance at the Sukamahi Pusat Cikarang Village Office.
\end{abstract}

Keywords: Compensation, Work Discipline, Achievement Motivation Performance

\section{Background}

\section{INTRODUCTION}

The world of offices and services today is expected to produce good employee performance for the development of offices in a better direction. The office should be able to improve its internal performance. The success of the office is influenced by several elements, one of the important elements is the existing HR, because HR is the perpetrator from all the beginning of planning to the evaluation that is able to utilize other resources owned by the organization or office. In human resources in government agencies, it is expected that there are really qualified human resources and meet the needs of the community. Especially in agencies engaged in the field of service. In some cases, the public complains about the

Fitri Rezeki \& Rahmat Hidayat. The effect of compensation, discipline and achievement motivation on employee performance 
underperformance health of employees working for government agencies, starting from the speed of work, accuracy and also some very crucial things that should not be happened.

A valuable work can be created by the feasibility of a leader in the agency or office to provide support to employees with a decent environment, motivation, a sense of perfect work discipline and the acceptance of appropriate reciprocity by each employee, will be able to provide additional morale of employees in carrying out the task. But in reality, the office does not pay much attention to the management of qualified human resources. In fact, the ability of a human being is very influential in every change to the success of an office. (Tanod Nanda Aromega, 2019)

The problem that often occurs in the Sukamahi Cikarang Pusat Village Office that is engaged in service to the community is related to the motivation of work that decreases due to bonuses and wages are less of a major factor so that discipline in work decreases. Based on the findings of the problem that occurred at the Sukamahi Cikarang Pusat Village Office, I am interested to conduct research on compensation, competency of work discipline and motivation that will certainly have a positive impact for the office.

\section{REVIEW OF LITERATURE}

\section{Compensation}

Compensation based on team performance is more effective in motivating team efforts when team identity is weak. These results indicate that with the appropriate compensation received by the employee, eating will change the behavior of a team as needed. While various types of compensation will also later produce the highest output, improved good performance is also influenced by complement in a good way as well (Janell L.Blazovich, 2013).

Compensation is a complicated thing. In the case of compensation there is a viable or unworthy basis in rationality, and there can be reciprocity over the compensation and many factors of feeling from the aspect of employment. The main function of compensation is to empower employees or laborers in carrying out their duties and obligations in work (Mohammad Iman Tindow, 2014).

\section{Discipline}

The meaning of the word discipline can be translated into an attitude, and behavior in accordance with the rules of the organization or institution either in written form or not. Therefore, in its realization if an institution has tried most of the regulations obeyed by most employees or employees, then discipline can be enforced (Darmawan, 2013:41).

Discipline comes from many of ourselves, which is demonstrated by obeying and obeying all applicable regulations. Because disiplim comes from a deep self-will, the enforcement of discipline is the guidance of attitude to stick to every provision that applies in organusasi or isntitusi. Discipline can be interpreted as the implementation of management to strengthen the rules of organizational rules (Mangkunegara 2015:129).

Handoko (2011:208) holds that discipline is to carry out something that has been determined by a institution or institution in achieving a goal. Hasibuan (2007:193-194), the meaning of a discipline is to behave consciously and wholeheartedly, without coercion of something or rules that have been set so that a goal that is determined by an organization or

Fitri Rezeki \& Rahmat Hidayat. The effect of compensation, discipline and achievement motivation on employee performance 
isntitution. Siagian (20017:305) argues about disciplinary as well, he said that according to him a discipline in work is to do consciously and without coercion something that has been determined together in work, which is followed by many people, employees or employees at an agency, in order to achieve the vision and mission that has been set together as well.

Suyanto in his research in 2018 argued that discipline has a big influence on the performance of an employee working in an office. Because with discipline, an employee will carry out and carry out all his duties and obligations properly and correctly in accordance with the rules and targets that have been set and targeted by the office or institution. With high discipline, the performance of employees will also be high.

From all the explanations that have been presented taken from the opinions of writers and experts in the field of management above, we can draw a common thread or conclusion that discipline is the attitude and actions of a person in a place by carrying out his duties and work consciously and without coercion with the aim that the vision of the mission and regulations in the company or office can run well.

\section{.Achievement Motivation}

The meaning of the word motivation in language is encouragement or help by encouraging. Pushing here is not pushing by hand or energy, but pushing here is to give something that makes the object become pushed. Motivation is an activity that, a result in the activity is the desire of someone to do something with the help of the encouragement. McCleland in Djiwandono (2014:122) says that humans are social beings, meaning that humans cannot live alone without the help of others.Manusis also lives sometimes with the influence of others, such as the influence of family, the environment, a place to study or an office where work. This place is the influence of a human being in behaving, learning and working. Then a good human being is a human being who lives and is influenced by a good environment. Family environment, residential environment, school or office.

Hilgard (in Dendik Surya Wardana Journal, 2013) argues that the motivation of achievement is a driving tool that exists in the person in doing something in a certain place and with a certain purpose. A child will be motivated by his family by trying to be a good member or child according to what is in the house. A student will be motivated by the school environment and strive to be a good and accomplished student in the community, according to what the school wants and will be motivated by the school environment. Likewise, a laborer or employee, with the environment in the office or organization will try to do the best in accordance with the vision and mission in the office or in the agency.

According to Murray (Winkle, 2004) in his research that the motivation of achievement is an attitude of a person to try to do the best and exceed others in work, which the work is in accordance with the rules set by the relevant party and in accordance with the objectives of the company, organization or institution. This motivation is created thanks to the environment that is conditioned so that an employee or employee races to be and do the best from other friends in order to excel.

\section{Performance}

The meaning of this performance is the quality of an activity, such as work or learning where the quality is in accordance with what has been set by the standard set as well. Performance or job performance is to perform and carry out with good obligations, duties and employment that has been required by the company or agency or organization to an employee or employee who works in that place that has a specific purpose (Banni, 2013:10).

Fitri Rezeki \& Rahmat Hidayat. The effect of compensation, discipline and achievement motivation on employee performance 
Mangkunegara in 2017 said that, Performance is the result of a person's work that is seen from the good or bad of his work, the little or much of the result of the work in accordance with the rules that have been set and the work charged to him. Prawirosentono in 2018 argues that performance is the responsibility of a person in his or her institution who has given him responsibility, to carry out his obligations. By carrying out these responsibilities must be carried out properly and responsibly.

Mangkunegara in 2011 argued that employee performance is a good work result and how much an employee can carry out his obligations in accordance with the work given to him. Another opinion of Sedarmayanthi is that performance is also the result of work that can be obtained by employees, both regulatory processes and agencies, where the results of the work can be shown tangible evidence both in terms of quality and quantity (Novelisa, 2016).

In this research, we as researchers advanced three hypotheses, namely:

1. Compensation Allegedly affects the performance of Sukamahi Cikarang Pusat Village Office Employees.

2. Work Discipline Allegedly affects the performance of Sukamahi Cikarang Pusat Village Office Employees.

3. Achievement Motivation Allegedly affects the performance of Sukamahi Cikarang Pusat Village Office Employees.

\section{RESEARCH METHODOLOGY}

In this study, researchers used quantitative techniques. Basically this research method is a research method that utilizes the situation and conditions in real time that exist in the field. By presenting the data in calculations that are then obtained and the results are the conclusion of the study (Sugiyono, 2016:16).

\section{Research Design}

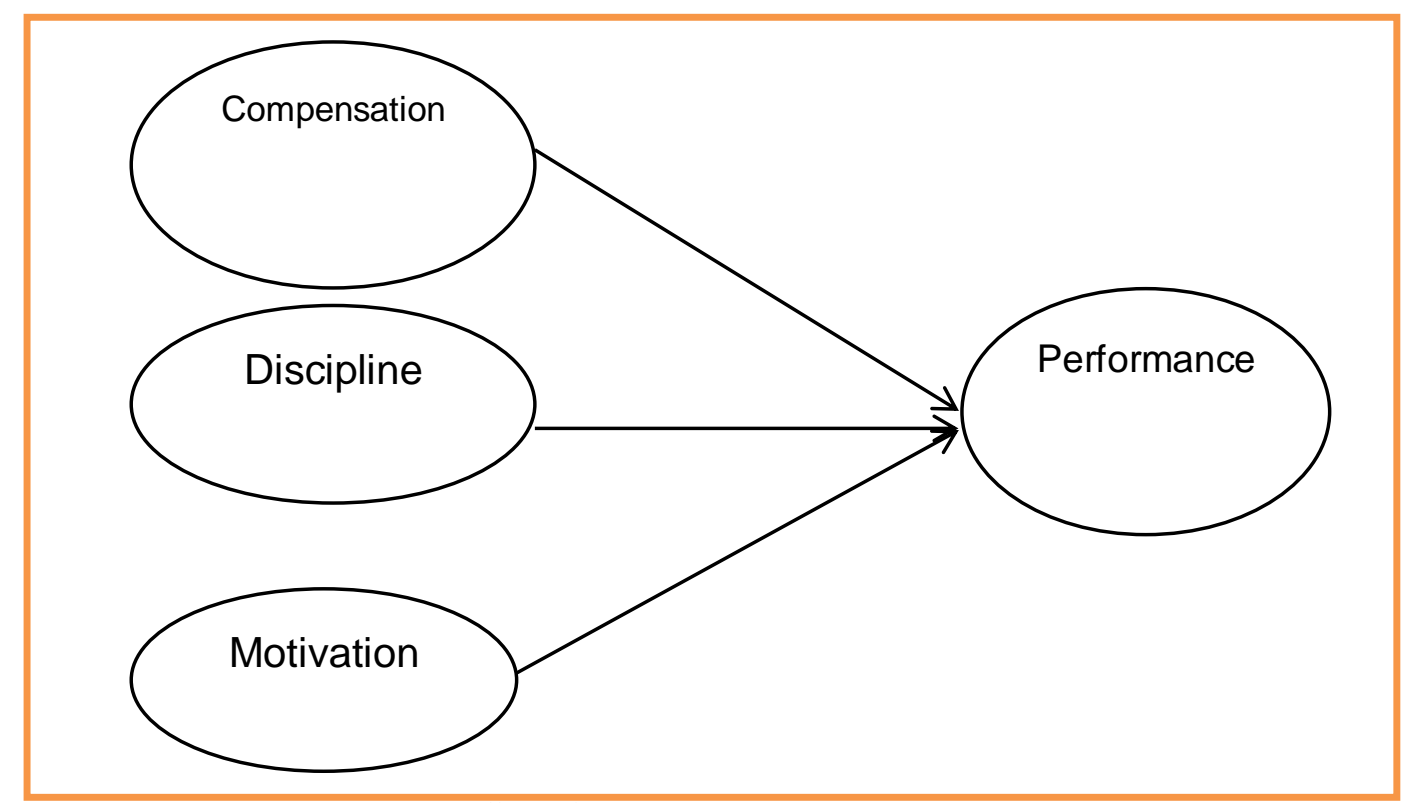

Fitri Rezeki \& Rahmat Hidayat. The effect of compensation, discipline and achievement motivation on employee performance 
Researchers chose the population in this study, namely all employees who worked in sukamahi cikarang pusat village office with 50 employees. This is the pupulation of all employees who work in Sukamahi Cikarang Pusat Village Office, meaning that the sampling technique is taking all populations as samples.According to Sugiyono (2013:122), the technique of taking saturated smple is performed when the number of the population is less than 100 people. Because the number of employees working in the office is less than 100 people, then all populations are used as samples.

In this research, we took some data, namely:

1. Retrieving library data. That is by looking for data from books, journals and literature related to the title of this study.

2. Data from research objects. Retrieve data from research objects by sharing questionnaires with the aim of knowing and obtaining data in accordance with the variables studied in this study (Sugiyono, 2016:142). Sugiyono argues that in measuring with the interval scale, researchers in this case use a Likert scale.And from that, then the questionnaire that will be given to the respondent, the questionnaire is equipped with five choices of answers.

In testing the questionnaire, the first thing to do is to test the validity. This validity test is conducted to determine whether each item or question given to the respondent is feasible or not (Ghozali, 2016:52). In this test there are terms r-table and r-count. The point is that if the $r$-countcalculation is greater than $r$-table then it is said that the item is worth. And on the contrary if the r-count is smaller than r-table, then the item can be said to be unfit.

In testing the questionnaire, the second thing to do is to test the reliability. This reliability test is carried out to find out whether each item or question given to respondents is realistic or not (Ghozali, 2016: 52). In this test there is the term nullally 0.6. The point is if the calculation of the results is greater than nulally then it is said that the item is reliable. And vice versa if the calculation is smaller than 0.6, then the item can be said to be unreliable. (Ghozali, 2016: 47).

The next test is to find out whether the data is normal or not, so we as researchers conduct a normality test. This test will be done by conducting a test with a histogram or plot. If the plot is evenly distributed, it is said that the data is normally distributed. But if the plots are clustered or stacked in one place, then it is said that the data is not spread normally.

After carrying out the validity test, the reliability test and the uni normality, then a multiple linear regression test was held. The goal is to find out whether each variable has an influence on variable $\mathrm{Y}$.

In the book written by Ghozali (2016: 97) the t test is also to determine the effect of each variable in nominal terms and what percentage of the effect is. In this study, there are three independent variables and one dependent variable, then each one will be tested.

\section{RESULTS AND DISCUSSIONS}

From the Figure 1, it can be seen that the normality test diagram curves upwards to form a curve, so it can be said that the data is spread normally.

Fitri Rezeki \& Rahmat Hidayat. The effect of compensation, discipline and achievement motivation on employee performance 


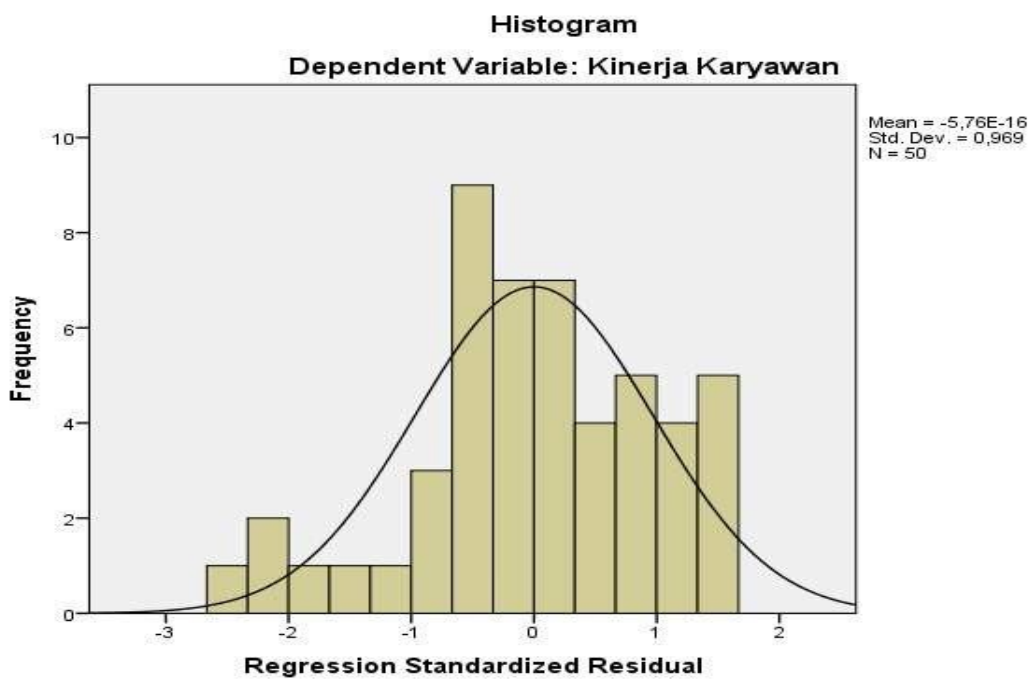

Figure 1. Normality Test

Table 1. Multicollinearity Test Results

\begin{tabular}{ccc}
\hline Model & Collinearity Statistics \\
\hline & Tolerance & VIF \\
\hline (Constant) & & \\
\hline Compensation & 0.976 & 1.025 \\
\hline Work Discipline & 0.979 & 1.022 \\
\hline $\begin{array}{l}\text { Achievement } \\
\text { Moti }\end{array}$ & 0.995 & 1.005 \\
\hline
\end{tabular}

Source: Processed Data SPSS 22, 2020

From the table 1 , we get a tolerance value greater than 0.1 , which is the compensation variable (X1) with a value of 0.976 . Work Discipline (X2) of 0.979 . The Achievement Motivation (X3) of 0.995 . and the VIF value is smaller than 10 in the Compensation variable (X1) of 1.025. Work Discipline (X2) with a value of 1.022 Achievement motivation (X3) with a value of 1.005 so that researchers can make conclusions that there is no and there is no multicollinearity between independent variables (compensation, work discipline and achievement motivation) in the regression model.

After processing the data with the SPSS 22 program, there are three outputs. The initial output is the compensation variable (exogenous 1), work discipline variable (exogenous 2), achievement motivation variable (exogenous 3 ) and employee performance variable $(Y)$. The relationship between each statement item with the statement item score. The value of the relationship compared to the $r$ table is sought at an accuracy of 0.05 with two sides and the number $(n)=50$ or $(n-2)=48$, then the $r$ table results are 0.2787 .

Fitri Rezeki \& Rahmat Hidayat. The effect of compensation, discipline and achievement motivation on employee performance 
The result of the reliability statistical test shows that the existing statements have alpha coefficient, $r=0.761$. Therefore, researchers can continue the research because the score of Cronbach Alpha is 0.61 to 0.80 .

Table 2. Multiple Linear Equation Test Results

\begin{tabular}{|c|c|c|c|c|c|}
\hline \multirow{2}{*}{ Model } & \multicolumn{2}{|c|}{$\begin{array}{c}\text { Unstandardized } \\
\text { Coefficients }\end{array}$} & \multirow{2}{*}{$\begin{array}{c}\text { Standardized } \\
\text { Coefficients } \\
\text { Beta } \\
\end{array}$} & \multirow{2}{*}{$\mathrm{T}$} & \multirow{2}{*}{ Sig. } \\
\hline & $\mathrm{B}$ & Std. Error & & & \\
\hline 1 (Constant) & 5.695 & 5.978 & & 0.953 & 0.346 \\
\hline$X 1$ & -0.122 & 0.119 & -0.126 & -1.023 & 0.312 \\
\hline $\mathrm{X} 2$ & 0.227 & 0.111 & 0.252 & 2.046 & 0.047 \\
\hline X3 & 0.548 & 0.134 & 0.498 & 4.078 & 0.000 \\
\hline
\end{tabular}

Based on the results of multiple linear regression, the following equation is obtained: $Y$ $=5,695+-, 122 \times 1+, 227 X 2+, 548 \times 3$.

Description:

1. Based on the calculation, there is a constant with a value of 5,695 which means if the compensation (exogenous 1), the work discipline variable (exogenous 2), the achievement motivation variable (exogenous 3 ) and the employee performance variable $(Y)$. the value is 0 , so the score for the performance of the employee is 5,695

2. The value of Standardized Coefficients on the Compensation variable is $-0,122$ which means that if there is a change in Compensation (exogenous 1 ) by one unit then the Employee Performance $(Y)$ will change with a score of $-0,122$ points. Likewise if the value decreases.

3. The results of Standardized Coefficients on the Work Discipline variable (exogenous 2) are 0.227 which means that any change in the Work Discipline variable (exogenous 2) of one unit will result in a change in Employee Performance (Y) of 0.227 units. Likewise, if there is a decrease in

4. the result of Standardized Coefficients on the Achievement Motivation variable (exogenous 3 ) is 0.548 , which means that every change in the Achievement Motivation variable $(\mathrm{X} 3)$ by one point will result in a change in Employee Performance $(\mathrm{Y})$ of 0.548 units. Even if there is a decline

Testing on the partial test to get the results of the exogenous variables automatically has an effect or has a significant effect on the dependent variable $(Y)$.

Table 3. $t$ Test Result (Partial)

\begin{tabular}{|c|c|c|c|c|c|c|}
\hline \multirow[b]{2}{*}{ Model } & \multicolumn{2}{|c|}{ Unstandardized Coefficients } & \multicolumn{2}{|c|}{ Standardized Coefficients } & \multirow[b]{2}{*}{$\mathrm{T}$} & \multirow[b]{2}{*}{ Sig. } \\
\hline & $\mathrm{B}$ & Std. Error & Beta & & & \\
\hline $\begin{array}{ll}1 & \text { (Constant) }\end{array}$ & 5.695 & 5.978 & & & ,953 & 0.346 \\
\hline $\mathrm{X} 1$ & -0.122 & 0.119 & & -0.126 & -1.023 & 0.312 \\
\hline $\mathrm{X} 2$ & 0.227 & 0.111 & & 0.252 & 2.046 & 0.047 \\
\hline $\mathrm{X} 3$ & 0.548 & 0.134 & & 0.498 & 4.078 & 0.000 \\
\hline
\end{tabular}

Fitri Rezeki \& Rahmat Hidayat. The effect of compensation, discipline and achievement motivation on employee performance 
The Management Journal of BINANIAGA Vol. 06, No. 01, June 2021

p-ISSN: 2527-4317, e-ISSN: $2580-149 x$

$6^{\text {th }}$ Accreditation Rating: April 04, 2019-April 03, 2024

Based on data processing, it can be concluded that:

1. From the exogenous variable $1, t$ count -1.023 is smaller than $t$ table which has a value of 2012 which means that $\mathrm{H} 1$ is rejected.

2. From exogenous variable $1, t$ count 2.046 is greater than $t$ table which has a value of 2012 which means that $\mathrm{H} 1$ is accepted.

3. From exogenous variable 1 , $t$ count is 4.078 greater than $t$ table which has a value of 2012 which means that $\mathrm{H} 1$ is accepted.

\section{CONCLUSION AND RECOMMENDATION}

\section{Conclusion}

In the first variable, based on the results of the regression analysis, the calculation value is smaller than the table value of $t$, so a conclusion can be drawn that partially compensation has no effect on employee performance. In the second variable, based on the results of the regression analysis, the calculation value is greater than the table value of $t$ at the significance level. Thus it can be concluded that work discipline partially affects employee performance. In the third variable, based on the results of the calculation value is greater than the table value of $t$. Thus it can be concluded that achievement motivation partially affects employee performance.

\section{Recommendations}

1. Compensation has a surprisingly insignificant effect on the employee performance of the Sukamahi Cikarang Pusat village office. In this case the management of the Sukamahi Cikarang Pusat Village Office should be pay attention to bonuses and employee wages. Namely, by doing rewards for better employee performance.

2. Work Discipline has a significant influence on the employee performance of the Sukamahi Cikarang Pusat village office. In this case the management of the Sukamahi Cikarang Pusat Village Office should be pay attention to discipline in work and be improved again by its employees. Namely by conducting training training to develop competence in employees.

3. Achievement Motivation has a significant influence on the performance of the employees of the Sukamahi Cikarang Pusat Village Office, must continue to strive for and maintain the motivation of its employees even better and continue to prioritize it.

\section{REFERENCES}

Aromega, T.N. (2019) Pengaruh kompensasi dan disiplin kerja terhadap kinerja karyawan di yuta hotel manado. Universitas Sam Ratulangi Jurnal EMBA, 7(1). 741 - 750. ISSN 2303-1174.

Bintarti, S. (2015) Metodologi Penelitian. Jakarta: Mitra Wacana Media.

Fitri Rezeki \& Rahmat Hidayat. The effect of compensation, discipline and achievement motivation on employee performance 
Blazovich, J.L. (2013), Team identity and performance-based compensation effects on performance University of Hongkong. an international journal, 19. $153-184$. Emerald Insight.

Darmawan, D. (2013) Prinsip-Prinsip Perilaku Organisasi. Penerbit JP. Books. Surabaya.

Dessler, G. (2013), Human Resource Management Thirteenth Edition, New Jersey: Penerbit Prentice Hall.

Ghozali, I. (2016). Aplikasi Analisis Multivariate Dengan Program IBM SPSS 23 Edisi Kedelapan. Semarang: Badan Penerbit Universitas Diponegoro. Hal 47-215.

Hasibuan, M.S.P.. (2015). Manajemen Sumber daya Manusia Edisi Revisi, Jakarta : Bumi Aksara Hal 194.

Knights, A. (2018) Göteborgs Universitet, Achievement motivation and presidential effectiveness. Journal of Public Leadership nternational Journal of Public Leadership ( $)$ DOI 10.1108/IJPL-08-2018-0041.

Mohammad, IT. (2014) Disiplin Kerja, Motivasi Dan Kompensasi Pengaruhnya Terhadap Kinerja Karyawan Pada PT. Bank Sulut Cabang Calaca. Universitas Samratulangi Manado. Jurnal EMBA, 2(2). 1594-1606. ISSN 2303-1174.

Nugroho, A. (2016). Universitas Islam Batik Surakarta Pengaruh Komitmen Organisasi, Motivasi Berprestasi Dan Gaya Kepemimpinan Terhadap Kinerja Karyawan Pt Wangsa Jatra Lestari, Jurnal Bisnis dan Ekonomi (JBE). 23(2). 194 - 203 ISSN: 14123126.

Riyadi, S. (2011). Pengaruh Kompensasi Finansial,Gaya Kepemimpinan, dan Motivasi Kerja Terhadap Kinerja Karyawan pada Kantor Manufaktur di Jawa Timur. Jurnal $\begin{array}{lllll}\text { Manajemen dan } & & \end{array}$ http://cpanel.petra.ac.id/ejournal/index.ph p/man/article/viewArticle/18243

Sugiyono. (2012). Metode Penelitian Kuantitatif Kualitatif dan R\&D. Bandung

Suwati, Y. (2013). Pengaruh kompensasi dan motivasi kerja terhadap kinerja karyawan pada PT. Tunas hijau samarinda. Universitas Mulawarman. eJournal IImu Administrasi Bisnis, . 41-55 ejournal.adbisnis.fisip-unmul.org.

Suwatno; \& Donni P. (2011) Manajemen SDM dalam Organisasi Publik dan Bisnis. Penerbit Alfabeta. Bandung.

Wardana, SD. (2013). Motivasi Berprestasi Dengan Kinerja Guru Yang Sudah Disertifikasi. Jurnal ilmiah psikologi terapan, 01(1),

Fitri Rezeki \& Rahmat Hidayat. The effect of compensation, discipline and achievement motivation on employee performance 
The Management Journal of BINANIAGA Vol. 06, No. 01, June 2021

p-ISSN: 2527-4317, e-ISSN: $2580-149 x$

$6^{\text {th }}$ Accreditation Rating: April 04, 2019-April 03, 2024

This page intentionally be emptied

Fitri Rezeki \& Rahmat Hidayat. The effect of compensation, discipline and achievement motivation on employee performance

Page : 22 